\title{
Obesity With Hypertension Events In Taccorong Village, Bulukumba District
}

\author{
Wiwi Yuniarti ${ }^{1}$, Muriyati2, Hamdana ${ }^{3}$ \\ S1 Nursing Study Program, Stikes Panrita Husada Bulukumba, Indonesia ${ }^{1}$ \\ Departemen Community and Family Nursing , Stikes Panrita Husada Bulukumba, Indonesia ${ }^{2}$ \\ Departemen Surgical and Medical Nursing , Stikes Panrita Husada Bulukumba, Indonesia ${ }^{3}$
}

Corresponding Autor : Muriyati.stikes@gmail.com

\begin{abstract}
According to the world health organization 2015, says that hypertension is one of the main causes of premature death throughout and hypertension kills nearly 8 billion people every year in the world. Obesity is one of the risk factors for hypertension, because the accumulation of fat in the body, the higher a pearson's body mass index, the higher the risk of developing hypertension. The purpose of this study is to know the relationship between obesity and the incidence of hypertension in the village of Taccorong caused Bulukumba district in 2018. The population in this study was the obese comunity in Taccorong village, Bulukumba regency, a population of 68 restpondents, a sampling technique used by purposive sampling technique. This type of research is analytic research with cross sectional approach. The test used for the relationship of obesity with the incidence of hypertension in Taccorong village Bulukumba district in 2018. Is the Pearson Chi Square test, with the results of the study that obese respondents who experienced grade 1 hypertension were 18 respondents (85.7\%) and obesity 1 respondents who had hypertension grade 2 were 3 respondents $(14.3 \%)$. While the obese 2 respondents who experienced grade 1 hypertension were 6 respondents (31.6\%) and obesity 2 respondents who experienced grade 2 hypertension as many as 13 respondents (68.4\%). Based one the test results obtained values $(\mathrm{p}=0.000)$ then Ho is rejected and Ha is accepted. The conclusion of this study is that there is a correlation between obesity and the incidence of hypertension in Taccorong village, Bulukumba district in 2018. It is recommended for the Puskesmas Bonto Nyeleng Institution to pay attention to its working area to detect total obesity.
\end{abstract}

Keywords: Obesity, Hypertension

\section{INTRODUCTION}

Hypertension or high blood pressure is a condition where a person experiences blood pressure above normal (Muttaqin, 2012). According to WHO (2013) and JNC7 (2015) explained that a person is said to be hypertensive when systolic pressure is $40140 \mathrm{mmHg}$, while diastolic pressure is $\geq 90 \mathrm{mmHg}$. Based on WHO data (2015), it is said that hypertension is one of the main causes of premature death throughout and hypertension kills nearly 8 billion people every year in the world. Around 1.56 billion adults will suffer from hypertension and almost 1.5 million people each year in the South Asian region, and in the Southeast Asian region including Indonesia the incidence of hypertension cases has also increased by $28 \%$. 


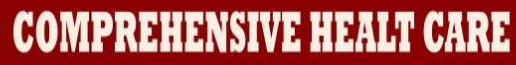

According to Riskesdas (2013) the prevalence of hypertension in Indonesia obtained through measurement of blood pressure at the age of $\geq 18$ years by $26.5 \%$. The 2016 National Health Indicators Survey showed prevalence increased to $32.4 \%$. Riskesdas 2013 data showed that the population that was obese reached $15.4 \%$, while in 2016 the adult population aged over 18 years who were obese was $20.7 \%$. And obtained the incidence of hypertension in obesity $13.5 \%$ this number will increase along with an increase in body mass index (Ministry of Health, Detik Health, 2017).

Based on data from the Bulukumba Health Office (2017) the number of cases of hypertension in 2017 was 13,795 people. This figure shows an increase from the previous year recorded in 2016 of 10,430 people. Based on data from the working area of the Bonto Nyeleng Community Health Center in 2016 there were 181 cases of hypertension. While in 2017 there were 615 cases of hypertension. The risk of developing hypertension in obese people reaches two to six times greater than normal bodied. Therefore, excess body weight is also a factor in the occurrence of high blood pressure. If this hypertension occurs prolonged, it will increase the risk of stroke, heart attack, heart failure and chronic kidney failure (Noviati, 2015).

Based on the results of an initial survey conducted by researchers in Taccorong Village, it was found that there were 68 people who were obese, with 64 women and 4 men. This is a problem that needs to be addressed, therefore there must be efforts to reduce the incidence of hypertension and obesity in the community through health education and public awareness to always behave healthy life. So that people realize that the incidence of hypertension and obesity can cause sroke and death. Unhealthy lifestyles such as, uncontrolled eating patterns, consumption of fast food, lack of physical activity (exercise) that causes obesity, which is one of the triggering factors for hypertension.

The results of previous studies were conducted by Sulastri, Elmatris, \& Ramadhani, (2012). The results found more than half of people with hypertension are obese, there is a significant relationship between obesity and the incidence of hypertension. This is in line with research by Natalia, Hasibuan, \& Hendro, (2015). There is a statistically significant relationship between obesity and the incidence of hypertension.

The purpose of this study was to analyze whether there is a relationship of obesity with the incidence of hypertension in Taccorong Village, Bulukumba Regency in 2018. 


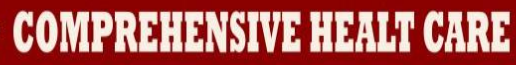

\section{MATERIAL AND METHODS}

The research design or research design is also arranged so that the researcher can get an answer to the research statement (Setiadi, 2013). Which aims to determine the relationship of obesity with the incidence of hypertension in D esa Taccorong Bulukumba Regency. Population is the whole subject of research to be studied (Setiadi, 2013). The population in this study were residents of Taccorong Village who were obese as many as 68 people. The sampling technique used for sampling in this study was carried out by means of non-probability sampling that is sampling not random or nonrandom. By using purposive sampling technique, where the aim of sampling is not based on strata, groups, or random, but based on certain considerations (Notoatmodjo, 2012).

The instruments used in this study The research instrument for the obesity variable is the observation sheet using a digital scale (GEA) and a meter body (stature meter / microtoice). Meanwhile, the instruments used for hypertension variables are blood pressure meters and stethoscopes. Data were analyzed based on measuring scale and research objectives using computerized program software. Data were analyzed by: (1). Univariate Analysis, Analysis is done to see the proportion. (2). Bivariate Analysis, Bivariate test is carried out to find the relationship between the independent variable and the dependent variable with the test used is chi-square when it meets the requirements, and fisher's exact test will be conducted as an alternative if the main test is not met. The confidence interval taken was $95 \%$ and the accepted significance limit if $\mathrm{p}<0.05$.

\section{RESULTS}

Table 1. Distribution of Characteristics in Taccorong Village, Bulukumba Regency

\begin{tabular}{lcc}
\hline Characteristics & $\mathbf{n}$ & Percentage (\%) \\
\hline Gender & 4 & 10.0 \\
Male & 36 & 90.0 \\
Female & & \\
Age & 18 & 45.0 \\
$21-35$ & 22 & 55.0 \\
$36-49$ & & \\
Level Of Education & 31 & 77.5 \\
Basic & 8 & 20.0 \\
Middle & 1 & 2.5 \\
Higher Education & & 90.0 \\
Profession & 36 &
\end{tabular}




\section{COMPRABHENSWE HEAH CARE}

Farmers

Teacher

\begin{tabular}{ccc} 
& 3 & 7.5 \\
& 1 & 2.5 \\
\hline Amount & $\mathbf{4 0}$ & $\mathbf{1 0 0 . 0}$
\end{tabular}

Based on (Table 1) shows the majority of respondents were female as many as 36 people (90\%), most of the age of the respondents were at the age of 36-49 as many as 22 people (55.0\%), the majority of respondents' education was basic education as many as 31 people (77.5\% ), most respondents work as housewives as many as 36 people $(90.0 \%)$.

Table 2. Distribution of Obesity Frequency by IMT Category in Taccorong Village, Bulukumba Regency

\begin{tabular}{lcc}
\hline Obesity & n & Percentage (\%) \\
\hline Obesity 1 (IMT 25-29,9) & 21 & 52.5 \\
Obesity 2 (IMT > 30) & 19 & 47.5 \\
\hline Hypertension & & \\
\hline Hypertension Grade 1 & 24 & 60.0 \\
Hypertension Grade 2 & 16 & 40.0 \\
\hline Amount & $\mathbf{4 0}$ & $\mathbf{1 0 0 . 0}$ \\
\hline
\end{tabular}

Based on (Table 2) shows the distribution of obesity frequency by BMI category, first-degree hypertension and second-degree hypertension in Taccorong Village. Obesity was most at respondents with obese category 1 as many as 21 people (52.5\%), while at least obesity 2 as many as 19 respondents (47.6\%). And based on hypertension most of the first-degree hypertension were 24 people (60\%), while at least grade 2 hypertension were 16 people (40\%).

Table 3. Distribution of Relationship between Obesity and the Occurrence of Hypertension in Taccorong Village

\begin{tabular}{|c|c|c|c|c|c|c|c|c|}
\hline & & \multicolumn{4}{|c|}{ Hypertension } & \multirow{2}{*}{\multicolumn{2}{|c|}{ Amoun }} & \multirow{3}{*}{$\begin{array}{l}P \\
\text { Value }\end{array}$} \\
\hline & & \multicolumn{2}{|c|}{$\begin{array}{c}\text { Hypertension } \\
\text { Grade } 1\end{array}$} & \multicolumn{2}{|c|}{$\begin{array}{c}\text { Hypertension } \\
\text { Grade } 12\end{array}$} & & & \\
\hline & & $\mathbf{N}$ & $\%$ & $\mathbf{N}$ & $\%$ & $\mathbf{N}$ & $\%$ & \\
\hline \multirow{2}{*}{ Obesity } & Obesity 1 (IMT25-29,9) & 18 & 85.7 & 3 & 14.3 & 21 & 100.0 & \multirow{3}{*}{0.000} \\
\hline & Obesity 2 (IMT>30) & 6 & 31.6 & 13 & 68.4 & 19 & 100.0 & \\
\hline Amount & & 24 & 60.0 & 16 & 40.0 & 40 & 100.0 & \\
\hline
\end{tabular}

Based on (Table 3) shows the relationship of obesity with the incidence of hypertension in Taccorong Village in 2018 where most of the 1 obese sufferers with grade 1 hypertension as many as 18 people (85.7\%) and the least obese 1 who have grade 2 hypertension as many as 3 people (14.3\%). Whereas obesity 2 who experienced grade 1 hypertension were 6 people (31.6\%) and most obesity 2 who experienced grade 2 hypertension were 13 people (68.4\%). 


\section{COMPRABHENSWE HAHW CARE}

This shows the tendency of differences in the percentage between the categories of obesity 1 and obesity 2 . Pearson chi-square test results obtained the results of $p$ is 0,000 . So it can be concluded that there is a relationship of obesity with the incidence of hypertension in Taccorong Village, Bulukumba Regency in 2018.

\section{DISCUSSION}

In this study shows that there is a relationship of obesity with the incidence of hypertension in Taccorong Village, Bulukumba Regency in 2018. Based on statistical results performed using the Pearson chi-square test, the value of $p=0,000$ is smaller than the value of $\mathrm{a}=(0.05)$. Then Ho is rejected and Ha is accepted. This proves that obesity is related to the incidence of hypertension in Taccorong Village, Bulukumba Regency.

Sutanto, (2010) obesity is one of the risk factors for hypertension. Cardiac output and blood volume circulation in obese hypertension sufferers are higher than in hypertensive sufferers who are not obese. Weight is one of the most closely related to hypertension, if a person's weight increases, the volume of blood will increase too so that the heart's burden to pump blood also increases. The greater the burden, the greater the workload of the heart in pumping blood throughout the body. Another possibility of insulin, which is a hormone produced by the pancreas to regulate blood sugar levels. If you gain weight, there is a tendency to increase insulin expenditure. With increasing insulin, sodium absorption in the kidneys will decrease. With increasing sodium in the body, the volume of fluid in the body will also increase. The more fluid including blood that is retained, the higher blood pressure will be (Nuraini, 2015).

Noviyanti, (2015) the risk of developing hypertension in someone obese tends to reach two to six times greater than in people who have normal weight or normal body. People who are overweight or obese due to fat accumulation have blood pressure that tends to be high because all the organs in the body are spurred to work harder in meeting large energy needs so that the heart also works harder due to fat deposits in blood vessel walls and levels fat in the blood also increases so that it triggers an increase in blood pressure. Evidenced by research Mardani, Gustina, Dewanto, \& Priwahyuni (2011) research results found that the prevalence of hypertension in the group of respondents who are obese is very high, reaching $40.8 \%$ or in other words 2 out of 5 people who are obese have hypertension. Statistical analysis using the chi-square test obtained p-value $=0.018$, which indicates a significant relationship between BMI with 


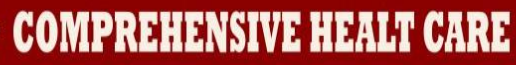

blood pressure and people who are obese have a 2 times greater chance of hypertension than normal/thin people.

This is in line with research conducted by Sulastri, Elmatris, \& Ramadhani, (2012). The relationship of obesity with the incidence of hypertension in the Minangkabau ethnic community in the city of Padang. Statistical analysis used was the chi-square test and the Independent sample T-test results of the study showed that there was a relationship between obesity and hypertension $(p=0.049)$. Supported by the research of Natalia, Hasibuan, \& Hendro (2015) there is a significant relationship between obesity and the incidence of hypertension. Statistical test results show the value of $\mathrm{p}=$ 0,000. This is in line with the study of Dewi \& Isnoviana (2017). The results showed that of 68 respondents, 46 respondents (68\%) who were obese had hypertension and 22 respondents (32\%) did not suffer from hypertension, using the chi-square test $\mathrm{p}=$ 0.000. So we get a significant relationship, there is a relationship of obesity with the incidence of hypertension.

Researchers argue that more obese 1 respondents were found to have grade 1 hypertension, compared to obesity 2 whereas obesity 2 had more degree 2 hypertension than obesity 1 . This was due to minimal activity in housewives, so they stayed more at home. Lack of physical activity, accompanied by frequent consumption of oily and fatcontaining foods. Unhealthy lifestyles where the education and knowledge of respondents are minimal makes most housewives become obese and hypertensive because it is difficult to avoid foods that should not be consumed. Even though most respondents know that the food they consume will have an impact on their health, but it is still consumed because it has become their daily needs. This is supported by Rudy Anggara, (2014). Obesity occurs because of an imbalance between energy intake and energy output, resulting in excess energy stored in the form of fat tissue. A bad lifestyle can cause obesity, including eating high-calorie fast food such as meat, fried chicken with various kinds of fried potatoes, noodles and others.

Lack of physical activity increases the risk of suffering from hypertension because it increases the risk of being overweight. People who do not do physical activity also tend to have higher heart rate frequencies so that the heart muscle must work harder with each contraction. The harder and often the heart muscle has to pump, the greater the pressure placed on the arteries (Nuraini, 2015). 


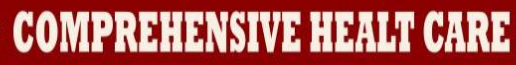

In people who are obese there is an increase in work on the heart to pump blood. Excessive body weight causes increased blood volume and expansion of the circulatory system. The greater the body mass, the greater the blood needed to supply oxygen and nutrients to the body's tissues. This causes the volume of blood circulating through the blood vessels to increase so that the pressure on the arterial wall becomes greater (Kembauan, Kandou, \& Kaunang, 2016).

\section{CONCLUSIONS}

Based on the results of the research above, it was concluded that there is a significant relationship between obesity and the incidence of hypertension in Taccorong Village, Bulukumba Regency in 2018. The results of this study may be used as material to increase insight in the field of research and increase knowledge about the relationship between obesity and the incidence of hypertension in Taccorong Village Bulukumba Regency 2018. As a reference data for the Bontonyeleng Community Health Center so that it can form a cadre that can record and detect obesity as a whole. It is recommended for the pustu in the village to add to the GERMAS program and to be improved especially on obese mothers. And the importance of counseling for the community so that there is awareness to behave in a healthy life, especially for obese people to avoid the risk of degenerative diseases.

\section{REFERENCES}

Muttaqin, A. (2012). Asuhan Keperawatan klien dengan gangguan sistem kardiovaskular. Jakarta: Salemba Medika.

Riskesdas. (2013). Riset Kesehatan dasar. Jakarta: Badan Penelitian dan Pengembangan Kesehatan Kementrian Kesehatan RI.

Kemenkes. (2017, Mei Rabu). Detik Health. Dipetik Maret Senin, 2018, from Kemenkes Sebut Kasus Hipertensi di Indonesia Terus Meningkat: http://m.detik.com

Dinas Kesehatan Provinsi Sulsel. (2015). Profil Kesehatan Provinsi Sul Sel. Sulawesi Selatan: Dinas Kesehatan Provinsi Sulawesi Selatan.

Dinkes Bulukumba. (2016). Seksi Pencegahan dan penanggulangan Penyakit.

Noviyanti. (2015). Hipertensi ( Kenali, Cegah \& Obati). Yogyakarta: Notebook.

Sulastri, D., Elmatris, \& Ramadhani, R. (2012). Hubungan Obesitas Dengan Kejadian Hipertensi. Majala Kedokteran.

Natalia, D., Hasibuan, P., \& Hendro. (2015). Hubungan Obesitas dengan Kejadian Hipertensi di Kecamatan Sintang, Kalimantan Barat. CDK-228/volume 42.

Setiadi. (2013). Konsep dan praktik Penulisan Riset Keperawatan (Edisi 2). Yogyakarta: Graha Ilmu.

Notoadmodjo, S. (2012). Metodologi Penelitian Kesehatan. Jakarta: PT Rineka Cipta.

Sutanto. (2010). Cegah dan Tangkal Penyakit Moderen (Hipertensi, Stoke, jantung, Kolesterol, dan Diabetes). Yogyakarta: ANDI. 
Mardani, S., Gustina, T., Dewanto, H., \& Priwahyuni, Y. (2011). Hubungan antara indeks Masa Tubu (IMT) dan Kebiasaan Mengkonsumsi Lemak dengan Tekanan Darah. Kesehatan Komunitas, Vol.1.

Dewi, Y., \& Isnoviana, M. (2017). Hubungan Obesitas dengan Hipertensi di puskesmas Kecamatan Majuharjo Kota Madium. INOVASI.

Nuraini, B. (2015). Risiko Faktor of Hypertension. Majority.

Anggara, R. (2014). Hubungan Obesitas Kejadian Hipertensi Pada Mahasiswa Fakultas Kedokteran dan Ilmu Kesehatan Universitas Muhammadiya Yogyakarta .

Kembauan, I. Y., Kandou, G., \& kaunang, W. P. (2016). Hubungan Obesitas Dengan Penyakit Hipertensi Pada Pasien Poliklinik Puskesmas Touluaan Kabupaten Minahasa Tenggara.

Artyaningrum, B., \& Azam, M. (2016). Faktot-Faktor Yang Berhubungan Dengan Kejadian Hipertensi Tidak Terkendali Pada Penderita Yang Melakukan Pemeriksaan Rutin. Public Health Perspective.

Black, J., \& Hokanson, J. H. (2014). Keperawatan Medikal Bedah. Singpore: Elsevier.

Dahlan, S. (2012). Langka-Langka Membuat Proposal Penelitian Bidan Kedokteran dan Kesehatan. Jakarta.

JNC7. (2015, Maret Minggu). Tatalaksana Hipertensi menurut The Sevent Join National Committe on Prevention, Derection, Evaluation and Treatment of High Blood Pressure .Dipetik Maret Minggu, 2018, from Farmakoterapi: http//www.Farmakoterapi.com

Kemenkes RI. (2016, April Minggu). MENKES: Sebagian Kasus Diabetes Sebenarnya Bisa Dicegah. Dipetik Maret Kamis, 2018, from Minisrty Of Health republic of Indonesia: http/www.depkes.go.id

Kusuma Dharma, K. (2017). Metodologi Penelitian Keperawatan. jakarta: TIM.

Lasianjayani, T., \& Martini, S. (2014). Hubungan Antara Obesitas dan Perilaku Merokok terhadap Kejadian Hipertensi. Berkala Epidemiologi.

Mahmudah, S., Maryusman, T., Ayu, F. A., \& Malkan, I. (2015). Hubungan Gaya Hidup dan Pola Makan dengan Kejadian Hipertensi pada Lansia di Kelurahan Sawangan Baru. Biomedika, Vol 7.

Mardani, S., Gustina, T., Dewanto, H., \& Priwahyuni, Y. (2011). Hubungan antara indeks Masa Tubu (IMT) dan Kebiasaan Mengkonsumsi Lemak dengan Tekanan Darah. Kesehatan Komunitas, Vol.1.

Mila, M., Anida, \& Ernawati, Y. (2016). Hubungan Aktifitas Fsik Dengan Tekanan Darah Pada lansia di Dusun Miri Desa Sriharjono Imogiri Bantul.

Muriyati, \& Syamsuddin. (2018). Dasar- Dasar Overweight Obesitas Aerobik. Babadan Ponorogo Jawa Timur Indonesia: Wade Group.

Muttaqin, A. (2012). Asuhan Keperawatan klien dengan gangguan sistem kardiovaskular. Jakarta: Salemba Medika.

Nova, M., \& Yanti, R. (2017). Faktor-Faktor yang Berhubungan dengan Obesitas pada Orang Dewasa di Kota Padang Panjang. Volume 1.

Nurarif, A. H., \& Kusuma, H. (2015). Aplikasi Asuhan Keperawatan Berdasarkan Diagnosa medis dan Nanda NIC-NOC, Jilid 2. Jogjakarta: Mediaction.

Ramadhan, M. D., Masyitah, D., \& Syauqy, A. (2015). Hubungan Indeks Massa Tubuh dengan Tekanan Darah pada Penderita Hipertensi di Poliklinik Penyakit Dalam Rumah Sakit Umum Daerah Raden Mattaher Jambi. 